\title{
Regulatory Reform in the BRItish Columbia Petroleum Industry: The OIL and Gas Commission
}

\author{
MURRAY RANKIN, SANDY CARPENTER, \\ PATRICIA BURCHMORE, AND CHRISTOPHER JONES
}

The authors provide an overview of British Columbia's Oil and Gas Commission by examining the policy reasons behind its creation, the structure of its governing act, and the interaction between the Commission and other government agencies. Particular attention is paid to the Commission's role with respect to First Nations, both by consideration of the Commission as an agent of the Crown, in relation to s. 35 of the Constitution Act, 1982 and various memoranda of understanding existing between the Province of British Columbia and First Nations, as well as by reference to specific provisions contained within the Commission's governing act.
Les auteurs présentent la Commission britannocolombienne du gaz et du pétrole en examinant les motifs qui ont présidé à sa création, la structure de ses statuts et ses rapports avec d'autres organismes gouvernementaux. Ils accordent une attention particulière au rôle de la Commission envers les autochtones - à titre d'agent de la Couronne, en regard de l'art. 35 de la Loi constitutionnelle de 1982 et de divers protocoles d'entente conclus entre la Colombie-Britannique et les Premières nations, ainsi que par renvoi à des dispositions précises des statuts de la Commission.

\section{TABLE OF CONTENTS}

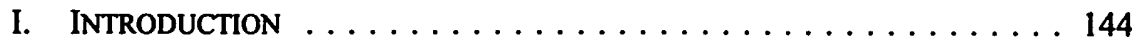

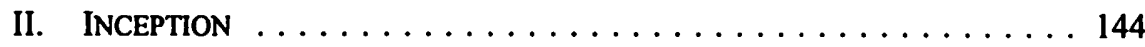

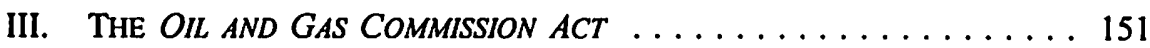

A. THE COMMISSION'S RESPONSIBILITIES $\ldots \ldots \ldots \ldots \ldots \ldots 152$

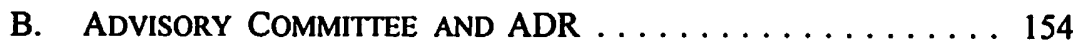

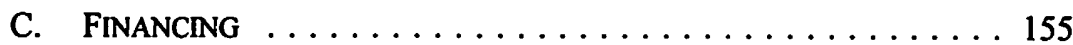

IV. THE COMMISSION'S LEGAL

OBligations To FIRST NATIONS $\ldots \ldots \ldots \ldots \ldots \ldots \ldots \ldots . \ldots \ldots$

A. SECtion 35 OF the Constitution $\ldots \ldots \ldots \ldots \ldots \ldots 156$

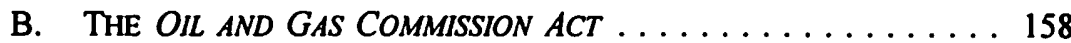

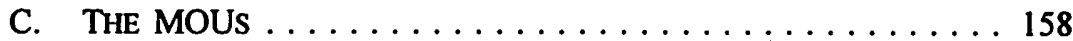

V. RELATIONSHIP BETWEEN THE COMMISSION

AND OTHER GOVERNMENT AGENCIES $\ldots \ldots \ldots \ldots \ldots \ldots \ldots 163$

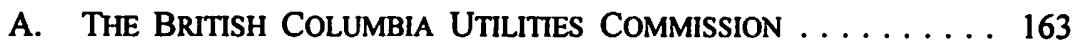

B. THE BRITISH COLUMBIA ENVIRONMENTAL

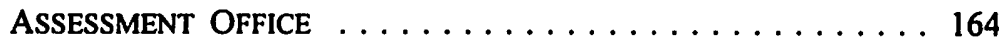

C. THE MINISTRY OF ENVIRONMENT, LANDS AND PARKS . . . . 165

D. THE MINISTRY OF FORESTS $\ldots \ldots \ldots \ldots \ldots \ldots \ldots 165$

E. THE MINISTRY OF ENERGY AND Mines $\ldots \ldots \ldots \ldots \ldots \ldots 166$

VI. COMPLIANCE AND ENFORCEMENT $\ldots \ldots \ldots \ldots \ldots \ldots \ldots \ldots \ldots$

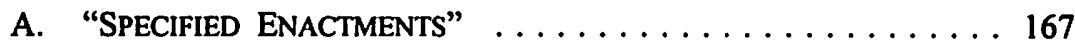

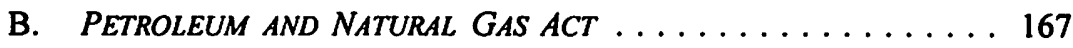

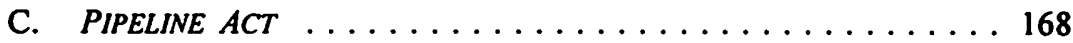


Very simply, in the oil and gas industry, the government saw the potential for substantially increased production and industrial activity in the province with a corresponding boost for government revenues. While already making a significant contribution to industrial activity in British Columbia, there were strong indications that the oil and gas industry had the potential to expand significantly. Demand, particularly for natural gas, was projected to remain strong for the next decade. ${ }^{5}$ Moreover, relative to Alberta and Saskatchewan, the British Columbia production-to-reserve ratio remained relatively low $^{6}$ and, again relative to Alberta, the British Columbia portion of the Western Canada Sedimentary Basin remained unexplored. ${ }^{\text {? }}$

The quid pro quo was a reduction in oil and gas levies on the industry and, most relevant for this article, the simplification of approvals required for oil and gas exploration and development. The necessity for more efficient regulation was stressed in a February 1998 Golder Associates study, commissioned by the Canadian Association of Petroleum Producers. ${ }^{8}$ Among other things, Golder Associates found overlapping legislation, inconsistent legislative application, an overly complex approval process, lack of departmental cooperation, and a shortage of human resources, particularly at peak times. One comment made by an unattributed industry representative was that Alberta had a one-window approach with understandable rules and time frames. The same was true in British Columbia in theory but not in practice. According to Golder Associates, if regulatory reform did not occur quickly, several companies in the Peace River region planned to withdraw their investment in British Columbia entirely. ${ }^{9}$ Among Golder Associates' recommendations was the following:

\begin{abstract}
The key element in terms of comprehensive, long-term progress is establishment of a highly committed group of Government and Industry representatives working cooperatively toward achievable goals. The Provincial Government must recognize the regional uniqueness of the current situation and allow those responsible for implementation free scope in identifying both areas of concerns and probable solutions. ${ }^{10}$
\end{abstract}

The Commission, staffed with a group of officers dedicated to the consideration of applications necessary for upstream activity, with single-window authority over all of the principal approvals required for oil and gas development, became the means to achieve a streamlined approval process.

While the impetus for more efficient regulation of upstream activities was clear, the provincial government was equally anxious to ensure that an expansion of activity in the British Columbia oil patch would not be at the expense of environmental standards

S KPMG, Overview of the British Columbia Oil and Gas Industry (February 1998) at 18 [unpublished].

$6 \quad$ Ibid. at 34.

7 Province of British Columbia, Ministry of Energy, Mines and Petroleum Resources, Upstream Regulatory Reform Project, Report of the Core Group (December 1995) at 12 [unpublished]. Golder Associates Ltd., Report on Regulation of the Oil and Gas Industry in British Columbia (February 1998) [unpublished]. 
amalgamating existing separate permits; and, finally, creating an agency of government with staff seconded from existing ministries, issuing the same permits as required under existing legislation but through a single wicket. The last option was chosen for a number of reasons. The most important were that this option: (1) involved the least disruption of ministry staff as well as ensuring continuity of their expertise; (2) allowed greater control by government in an industry which has a significant impact on government revenue and public policy; and (3) contemplated the potential role of the Commission in reaching agreements with First Nations and in carrying out the government's consultative obligations, which will be discussed further below.

Whether the new Commission would simply continue to issue the same approvals then handled by government ministries was also discussed. There was an obvious, although perhaps superficial, attraction in creating a "super permit," amalgamating all of the permits necessary for the upstream industry. The idea for a single permit seemed to parallel the single window through which it would be issued. Although this option may be the subject of future regulatory change, it was rejected in the short term for a number of reasons. Chief among these was the very short legislative schedule which the government hoped to achieve. Amending all of the legislation through which permits and approvals are granted so as to create a new single approval was simply not practicable in the short time available. In addition, it seems that the sheer number of approvals, which would vary depending on the proposed activity, did not significantly contribute to the difficulty of achieving project approval. By contrast, it was hoped that the process would be streamlined by approval through a single agency.

Exactly what portion of the industry would be regulated also had to be determined. The first obvious limitation was the Constitution, which precluded regulation of much of the British Columbia pipeline system, namely the Westcoast Energy system. ${ }^{12}$ In addition, both government and industry wanted to avoid making the Commission another level of bureaucracy with elaborate procedural trappings such as oral hearings and legal representation. This would defeat the purpose of streamlining the application and review process. In addition, in the British Columbia Utilities Commission ("BCUC") there already existed a tribunal which conducted oral hearings, particularly in advance of granting certificates of public convenience and necessity, or for rate approvals. Rather than making determinations on the economic regulation of the industry or deciding on utility infrastructure additions, the Commission was established to handle the essential permits and approvals necessary at the gathering and processing end of the oil and gas business.

Another matter considered during the drafting stage was the corporate form of the Commission. As noted, the government did not want to set up another administrative tribunal like the BCUC or the National Energy Board. Therefore, the tribunal model was discarded. Another possibility which was discussed was a "corporation sole." However, the limits usually placed on the activities of a "corporation sole" led to a rejection of this model as well. This quickly led to the adoption of a corporate model to provide the Commission with financial and administrative flexibility as well as a 
and intermeshing legislation required significant input from a large number of ministries. In short, only those who had worked in oil and gas regulation really knew if the idea of a single-window agency such as the Commission was practicable. Personnel from the Ministry of Energy and Mines were, of course, particularly central to the process of determining the appropriate parameters of the Commission's mandate and in providing comments on proposed legislation. However, consultations with officials from the Ministry of Environment, Lands and Parks, the Ministry of Forests, the Ministry of Transportation and Highways, and the Ministry of Small Business, Tourism and Culture (regarding heritage conservation) were also essential in zeroing in on the precise content of legislation that was essential in the regulation of upstream activities.

Particularly in view of the Supreme Court of Canada's decision in Delgamuukw v. $R .{ }^{19}$ it was important that First Nations be satisfied that the Commission could actually improve the consultation process respecting oil and gas gathering and processing without derogating from the government's constitutional obligations in this respect. In June 1998, the Treaty 8 Tribal Association ("T8TA") expressed several concerns about the proposed form of the Commission. Among those concerns was T8TA's view that the establishment of the Commission would be in conflict with a process of negotiation previously commenced between it and the province. However, after June 1998 the government took steps to ensure a more active role by First Nations in the implementation of the Commission. In particular, a key representative of a Treaty 8 band was included on both the Reference Group, composed of stakeholders and the Operations Sub-Committee, which conducted the detailed planning leading up to Commission implementation. These two bodies will be described more fully below.

Finally, it was also considered vital for the environmental community to be favourably disposed toward the new Commission. From an early stage, its members expressed their general support for the Commission. This seems to have resulted from the manner in which the Commission was intended to integrate the various decisions surrounding oil and gas development, bringing together under one roof issues such as resource conservation, road construction, timber cuts, and stream preservation or rehabilitation. This integration of economic and environmental considerations was consistent with the environmental movement's desire to take a holistic approach to oil and gas regulation. Wayne Sawchuk, President of the Chetwynd Environmental Society, was a well-respected member of the Operations Sub-Committee.

During the consultation period leading up to the introduction of legislation, it became obvious that, if the Commission was to get off to a smooth start, detailed planning would be obligatory. As a result, a process was established under the direction of a veteran public servant, Bruce McRae, to oversee the implementation of the Act. On the macro level, a Reference Group composed of stakeholders was established to provide advice and guidance. On the ground level, an Operations Sub-Committee and subordinate working groups conducted the detailed planning. The role of the Operations Sub-Committee was summarized as follows in a "Work Plan": 
Issues to be considered will include the possibility of grouping a series of facility applications into a project application....

\section{Working Group 2 - Establish Alternative Dispute Resolution Policies}

Assignment:

Develop a recommended policy for the Commission respecting Alternative Dispute Resolution (ADR). This would include an identification of acceptable mechanisms, and development of policies and procedures which will encourage the use of ADR to settle disputes....

\section{Working Group 3-Role of Commission in Planning Matters}

Assignment:

Recommend the appropriate roles for the Commission and its staff in the land use and tenure planning processes. This group is not intended to change established planning procedures but only to deal with the appropriate role for the Commission....

\section{Working Group 4-Regulation of Ongoing Operations}

Assignment:

Review existing practices with respect to the ongoing regulation of oil and gas operations and make appropriate changes in preparation for transfer of these responsibilities to the Commission. Identify the need for MOUs or other agreements with Government Ministries respecting inspection and enforcement. Review existing regulations for necessary changes and make recommendations for required amendments....

\section{Working Group 5 - Memorandums of Understanding}

Assignment:

Review the need for Memorandums of Understanding (MOUs) with Government Ministries, identify the issues at stake, negotiate as appropriate and draft recommended MOUs between the Commission and the Ministries.... ${ }^{20}$

\section{THE OIL AND GAS COMMISSION ACT}

In broad terms, the Commission's mandate is to streamline the process of obtaining approval for upstream ${ }^{21}$ activities by providing a single window for necessary permits and approvals, thereby assimilating the essential permits and licenses now granted by various ministries. While streamlining the approval process, the purpose clause in the Act also requires the Commission to promote the sound development of the oil and gas sector, inter alia, by "fostering a healthy environment, a sound economy and social well being": 
Unlike the "specified enactments," powers under the Petroleum and Natural Gas Act and the Pipeline Act have been transferred to the Commission by means of a direct amendment of those statutes, which was necessary for administrative efficiency. As a general rule, those portions of the Petroleum and Natural Gas Act and Pipeline Act which deal with surface tenure have been transferred to the Commission. Those dealing with subsurface tenure (including, for example, exploration permits, classification of permits, petroleum and natural gas leases, and disposition of Crown reserves and drilling licences under ss. 41, 42, 50 and 71 of the Petroleum and Natural Gas Act) remain with the Ministry of Energy and Mines and substantially will be exercised by the Director of Petroleum Lands, a newly designated post.

The reason for excluding subsurface tenure was the extensive policy function that accompanies the issuance of this kind of tenure. This is consistent with the treatment of the policy-making function, which continues to rest primarily with government and not the Commission. The limited emphasis on a policy-making role for the Commission is designed to emphasize its role as the single window for "ground level" approvals.

The Commission must exercise the powers and discharge the responsibilities under the "specified enactments" in accordance with the statute containing the specified enactment. The statutes containing the "specified enactments" continue to apply after the Commission has issued an approval. For example, any rights of appeal under existing statutes continue to apply with respect to Commission decisions (e.g. appeals under the Waste Management Act and Water Act continue to be the domain of the Environmental Appeal Board). ${ }^{28}$

The complexity of certain acts has necessitated specific arrangements with some government ministries. Subsection 17(3) of the Act, for example, requires the Commission to consult with the Ministry of Forests before issuing road use permits. Road use permits involve the right to use a road owned by another party (the roads are, in many cases, owned by the Ministry of Forests), and detailed coordination is necessary to address safety and maintenance concerns.

A major issue which emerged in the preparation of the Act related to the enforcement of "specified enactments." Subsection 17(4) of the Act provides that the Commission and the line ministries are each responsible for enforcement in relation to the "specified enactments." The Ministry of Environment, Lands and Parks and the Ministry of Energy and Mines already coordinate enforcement efforts related to oil and gas in the Northeast, and MOUs have been, or will be, developed between the Commission and the line ministries to ensure enforcement continues to be well coordinated. Enforcement of the Forest Practices Code will remain with Ministry of Forests compliance and enforcement staff. ${ }^{29}$ With 400 trained compliance and enforcement officers already in place, it was considered most inefficient for the Commission to duplicate this expertise. 
The triggering of ADR on a specific issue need not delay the review process for the entire application.

For example, downhole issues should not hold up the rest of an application review. ${ }^{33}$

The roles of the advisory committee and ADR are brought together in s. 9. This section allows the advisory committee to request the Commission to reconsider a decision by sending it out to ADR. The reconsideration would be subject to regulations setting out timelines on the exercise of this aspect of the Commission's responsibilities. ${ }^{34}$

Commission reconsideration is not possible if there is already an appeal mechanism built into the legislation under which the Commission's decision was made (e.g., most decisions under the Pipeline Act and the Petroleum and Natural Gas Act would qualify for reconsideration under s. 9; most decisions under the Waste Management Act and the Water Act would not). The only exception to this general rule is a decision to suspend or cancel a licence to cut timber, which for oil and gas purposes has been transferred to the Commission. Currently, under the Forest Act these decisions, when made by the Ministry of Forests officials, can be appealed within the Ministry of Forests and then ultimately appealed to an independent appeal body. This body will be called the Forest Appeals Commission once the requisite amendments to the Forest Act have been proclaimed. To avoid a situation where a decision of the Commission is reviewed by a Ministry of Forests official, the operation of this section has been suspended in the context of oil and gas activities. ${ }^{35}$

If the Commission grants the advisory committee's request, the effect of the Commission's decision is suspended until a new decision is made. Nothing in this section affects a person's right to seek judicial review of the Commission's original decision or the second decision.

\section{FinanCing}

The Commission is also designed to have a large measure of financial independence. The Commission is funded by revenues derived from levies on production and from applications and issuance fees for approvals and other authorizations under the Petroleum and Natural Gas Act and the Pipeline Act. Approximately 55 percent of total Commission revenues are derived from levies and 45 percent from fees. Increased fees for applications for activities under the Petroleum and Natural Gas Act were approved and implemented in October 1998. Amendments to the fee structure under the Pipeline Act were delayed until consultations with the pipeline industry could be completed. These fees were published on 9 June 1999, as an amendment to s. 20 of the Pipeline Regulation. ${ }^{36}$

Online: Oil and Gas Commission <http://www.ogc.gov.bc.ca/stakeholders/processes/adrprocess. htm> [emphasis added]. Supra note 1, ss. 9(3)-(4).

Ibid., s. 17(6).

B.C. Reg. 360/98; see BCOGC, Information Letter OGC 99-08, "New Fees Under the Pipeline Act" (9 June 1999). 
within its jurisdiction, the Commission can only authorize the infringement of aboriginal or treaty rights where this is "justified."

The courts have established a series of tests to determine whether an aboriginal or treaty right might be infringed by a government action and whether such infringement is justified.$^{40}$ Accordingly, when the Commission considers authorizing an activity that may infringe aboriginal or treaty rights, these tests establish a standard to which the Commission should adhere in making its decisions.

A comprehensive review of these tests is beyond the scope of this article. However, one point is worth noting since, while it is not unique to the Commission, it may distinguish the Commission's legal obligations to First Nations from the standard that has to be met by many other regulatory agencies. This point comes from the initial part of the test established by the Supreme Court of Canada in the Sparrow decision. This part of the test can be summarized as follows: Does the purpose or effect of the government action interfere with an existing aboriginal or treaty right?

The majority of First Nations with which the Commission deals have treaty rights, specifically those provided by Treaty $8 .^{41}$ To date, the courts have applied the same test with respect to infringements of both treaty and aboriginal rights. ${ }^{42}$ However, the genesis of aboriginal and treaty rights are fundamentally different. Aboriginal rights and title are based on First Nations' activities. Treaty rights arise from a treaty between the First Nation and the government. Accordingly, the precise interpretation of these rights is a significant issue.

From the Commission's perspective, and perhaps the First Nations', the most significant interpretation issue is whether the Commission needs to consult with First Nations when lands are "taken up" for industrial development. Treaty 8 provides as follows:

And Her Majesty the Queen HEREBY AGREES with the said Indians that they shall have right to pursue their usual vocations of hunting, trapping and fishing throughout the tract surrendered as heretofore described, subject to such regulations as may from time to time be made by the Government of the country acting under the authority of Her Majesty, and saving and excepting such tracts as may be required or taken up from time to time for settlement, mining, lumbering, trading or other purpose. $^{43}$

The Supreme Court of Canada has recognized some geographical limitation on treaty rights where lands have been "taken up" in Alberta ${ }^{44}$ However, in Halfway River

42

43

44

This series of tests was originally set out in Sparrow, supra note 37 . It was subsequently refined in $R$. v. Gladstone, [1996] 2 S.C.R. 723 and Delgamuukw, supra note 19.

Canada, Treaty No. 8. Made June 21, 1899, and Adhesions, Reports, etc. (Ottawa: Queen's Printer, 1966).

See Cote v. R. (1996), 138 D.L.R. (4th) 385 (S.C.C.).

Supra note 41.

R. v. Badger, [1996] I S.C.R. 771. 
activities. The MOUs establish a consultation process and make provisions for certain financial contributions to the First Nations in relation to those activities.

The MOUs are similar in form. Some of the differences in substance are discussed below.

Each MOU starts with a "without prejudice" clause. These provide that MOUs are without prejudice to "potential negotiations for Treaty Land Entitlement or selfgovernment agreements; the Parties' rights, titles or interests except as specifically defined in [the MOUs]; and any future discussions, negotiations or agreement on matters not relating to the oil and gas sector activity."

Article II then sets out certain definitions. Article III sets out the purpose of the MOUs. The purpose clause in the MOUs are very similar. For example, the purpose clause in the West Moberly MOU reads:

\section{PURPOSE}

A. This Memorandum of Understanding establishes a framework:

1. To further develop and encourage the relationship between the Parties.

2. For consultation between the Province and WMFN regarding oil and gas sector related activity licensed by the Province within the Critical Community Use Area.

3. To create greater clarity as to how the Province will consult with WMFN.

4. To formalize and make transparent all transfers and exchanges between the Parties.

5. To enable WMFN to identify potential infringements of oil and gas sector related activity on its treaty rights, and review and process Provincial oil and gas referrals in a timely manner.

6. To assist the Province to avoid unjustifiable infringement of any existing rights of WMFN.

B. The intent of this Memorandum is to assist the Parties to achieve the following:

1. Establish a consultation process with time-lines, structures, authorities, and a method for resolution of disputes;

2. Define the roles and responsibilities of WMFN, the Province and the oil and gas industry, with respect to consultation processes related to oil and gas section related activity in the Critical Community Use Area in British Columbia;

3. Establish a formula, mechanism and process for the oil and gas industry to contribute to WMFN's capacity related to consultations for oil and gas activity;

4. Establish a formula, mechanism and process for the oil and gas industry to contribute to development initiatives undertaken by WMFN;

5. Ensure that companies, or their representatives, engaged in oil and gas sector activity in the Treaty Number 8 area within B.C. pay only those financial contributions to First Nations provided for under this Memorandum; 
go one step further: they provide for a "Consultation Area." However, they state in Article VII:

[T] he four First Nations reserve the right to be consulted on projects outside their Consultation Areas within the boundaries of the broader Treaty 8 territory, in the event that this is deemed necessary on a project-by-project basis by the Chiefs and Councils of the four First Nations,....99

The consultation process which is provided for consists of a series of steps depending upon the "probability of infringement." Activities with a low probability of infringement are intended to be designated as Level 1 , and the consultation process is to be completed within ten working days. Activities with a medium probability of infringement are designated as Level 2 , and consultation is supposed to be completed within twenty working days. Activities with a high probability of infringement are designated as Level 3 . While there is no set maximum time for consultation, the parties anticipated that consultations with respect to Level 3 activities generally would take approximately 120 working days.

There are no objective criteria to define which applications are to be treated as Level 1, Level 2, or Level 3. The Commission is presently working with the First Nations to clarify this issue.

Article VIII of each MOU provides for financial contributions to the respective First Nations. These are divided between a contribution towards "capacity costs" and a contribution towards "development initiatives." In return, the Fort Nelson Indian Band, West Moberly, and Halfway River First Nations agree that they will not

\begin{abstract}
request or accept any fees, levies, compensation or other charges from companies, or their representatives, engaged in oil and gas sector related activity during the term of this Memorandum, other than: those provided for under this Memorandum; charitable donations and gifts unconditionally and voluntarily made by a company to [WMFN] that are permitted under the Income Tax Act (examples could include educational scholarships and events sponsorships); those costs that may be incurred due to meeting legislative requirements; and costs of studies that are deemed appropriate under the terms of the consultation provisions of this Memorandum, and justified and agreed upon by [WMFN] and the Oil and Gas Commission.
\end{abstract}

Interestingly, the Prophet River and Blueberry River MOUs similarly provide that those First Nations will not request any fees, levies, compensation, or other charges. However, these MOUs do not prohibit the First Nations from accepting such fees.

The Prophet River and Blueberry River MOUs also provide that compensation for registered trappers is not prohibited by the MOUs and attempt to establish a separate process to resolve the issue of trappers' compensation. 
This is consistent with the MOUs where there are higher probabilities of infringement. However, where there is little or no probability of infringement, the MOU process still appears to require that these applications be sent to the appropriate First Nations. Accordingly, even where there is little infringement, the Commission may be required to conduct thorough consultation.

In addition, at common law, if a First Nation refuses to consult after reasonable, good faith efforts have been made to do so, the Commission would be in a position to make its own assessment of the likelihood of impact on the First Nation's rights, to determine how best to deal with this, and proceed to a decision. However, under the MOU process, if a First Nation is not acting in a manner the Commission believes it should, the Commission cannot simply ignore this and grant the permit or authorization in question. Rather, the Commission must either engage in a dispute resolution process under the MOU or terminate the MOU.

Finally, it is likely that the second group of MOUs extend the geographical area over which consultation needs to take place beyond what would be required at common law. The first group of MOUs generally define a given area within which consultation needs to take place. This likely corresponds generally to the area over which consultation would have to take place at common law. However, as mentioned, Article VII of the MOUs which were entered into with the Prophet River and the Blueberry River First Nations provide that

[t] he four First Nations reserve the right to be consulted on projects outside their Consultation Areas within the boundaries of the broader Treaty 8 territory, in the event that this is deemed necessary on a project by project basis by the Chiefs and Councils of the four First Nations;

This appears to broaden what would have been required under common law and requires the Commission to consult with First Nations under these MOUs when the Chief and Councils notify the Commission this is required.

In summary, there is a good deal of overlap between the duty to consult under s. 35 of the Constitution and the process under the MOU. However, the latter process may be the more onerous of the two. Finally, under the MOUs the Commission does not have the same ability to resort to unilateral action if it is running into difficulty consulting with a particular First Nation as it would at common law.

\section{RElationship BETWEEN THE COMMISSION AND OTHER GOVERNMENT AGENCIES}

\section{A. The British Columbia UTILITIES Commission}

The BCUC was created in 1980 pursuant to the provisions of the Utilities Commission Act. ${ }^{51}$ Following changes to its jurisdiction after the enactment of the 


\section{The Ministry of EnVironment, Lands and Parks}

The Ministry of Environment, Lands and Parks ("MOELP") is responsible for management of Crown lands in British Columbia and, in particular, for mapping, surveying, and the supervision of waste management and environmental issues. ${ }^{56}$

Certain applications formerly made to the MOELP pursuant to the provisions of the Land Act and the Waste Management Act are now made directly to the Commission. ${ }^{57}$ Applications considered and granted by the Commission under the provisions of the Land Act include the lease of Crown land, right of ways or easements over Crown land, and the licence to occupy Crown land in connection with an oil or gas or pipeline project. Applications considered and granted by the Commission under the provisions of the Waste Management Act include special waste storage and disposal and other permits and approvals relating to oil and gas and pipeline activities.

A company making an application to construct a pipeline pursuant to the provisions of the Pipeline Act is required to file a copy of the application with the MOELP. The Commission must have regard to all factors it considers relevant including the recommendations of the MOELP after its review of the application. The Commission is not required to consult with the MOELP prior to granting applications under the Land Act or the Waste Management Act.

Applications for these types of permits for a pipeline under federal jurisdiction still must be made to the MOELP.

\section{THE MinisTRY OF FORESTS}

The Ministry of Forests ("MOF") has responsibility over the timber, range, and recreation resources of British Columbia's unreserved public (Crown) forest land, which covers two-thirds of the Province of British Columbia. The British Columbia Forest Service, under the stewardship of the MOF, manages Crown lands for many uses including recreation, forage, timber, wilderness and, in co-operation with other agencies, water, fish, wildlife, tourism, heritage, energy, and minerals.

Approximately one-quarter of Crown forest land is managed for value, including commercial timber harvesting, as well as commercial activities managed by other agencies, including the oil and gas, and pipeline activities managed by the Commission. The Forest Practices Code establishes a single enforceable code of conduct for the Province of British Columbia.

Prior to the creation of the Commission, oil and gas companies which required cutting permits and road use permits were required to deal with the MOF. With the inception of the Commission, these companies are now able to deal with one agency 
The MEM, on behalf of the Commission, collects a levy in order to pay for a portion of the operating costs of the Commission.

The Commission is also assisting with the program initiated by the MEM and the MOELP to reduce benzene emissions from glycol dehydrators. ${ }^{60}$

\section{Compliance AND Enforcement}

\section{A. "SPECIFIED ENACTMENTS"}

Subsection 17(1) of the Act states:

For the regulation of oil and gas activities and pipelines, the commission, instead of the official named in a specified enactment,

a) has all the powers relating to a discretion, function or duty referred to in the specified enactment; and

b) is charged with all the responsibilities pertaining to that discretion, function or duty.

Subsection 17(2) of the Act states that the exercise of the powers by the Commission in carrying out each discretion, function, and duty referred to in a specified enactment and the responsibilities with which the Commission is charged remain subject, in all respects, to the legislation that contains the specified enactment.

The Act also provides that, subject to s. 17(5) which relates to the Forest Practices Code, the Commission and the appropriate officials under the various acts that contain the "specified enactments" are each responsible for enforcing the provisions of those acts in relation to the matters described in each specified enactment. ${ }^{61}$

\section{B. Petroleum and Natural Gas act}

The Act amends the Petroleum and Natural Gas Act by replacing the majority of the Minister's responsibilities and authority under the Petroleum and Natural Gas Act with those of the Commission. The Minister and the Commission both have the authority to enter a location to examine and inspect for the purposes of the Petroleum and Natural Gas Act.

The Commission has the responsibility to issue a certificate of restoration respecting a well, test hole, or production facility. The Commission may also cancel a well authorization in the circumstances set out in s. 86 of the Petroleum and Natural Gas Act or suspend a well authorization as authorized by s. 87 of the Petroleum and Natural Gas Act.

61 Supra note 1 , s. 17(4). 


\section{CONCLusion}

The Commission has been criticized for not achieving its central goal of providing a single window for the efficient regulation of upstream oil and gas activities. For example, there have been criticisms of the awkward arrangement whereby the Commission can declare a company to be a common carrier, while the BCUC is given the task of determining the terms of conditions under which the carrier will provide service.

Unquestionably, the Commission has difficulties which must be worked out. In addition, it is clear that the Commission does not have authority over every conceivable approval required for oil and gas development. In part, this is a result of the complexity of the task of creating a true single-window agency. More importantly, the Commission's goal is to be the single window for the core permits and approvals which are required, not for permits which might on occasion be needed. Establishing expertise within the Commission to handle seldom-sought approvals would not be administratively efficient.

That said, it is worth recalling that the Commission is in its infancy. If the current structure shows promise, and practice demonstrates that other permits and approvals could be most efficiently administered by the Commission, the Commission's mandate may be altered through legislation or regulation.

The essential structure of the Commission and its responsibilities are good omens. By drawing under one roof a myriad of approvals, which previously had been granted by a variety of government departments and agencies, the approval process should become more transparent and efficient. In addition, the role of the Commission in establishing agreements and working with First Nations should assist in this most complex aspect of proceeding with upstream activities. 